DOI: 10.20472/BMC.2017.006.021

\author{
BONGINKOSI ZWANE \\ Mangosuthu University of Technology, South Africa \\ CELANI NYIDE \\ Durban University of Technology, South Africa
}

\title{
SMME ATTITUDES TOWARDS FINANCIAL BOOTSTRAPPING: A PERSPECTIVE FROM A DEVELOPING ECONOMY
}

\begin{abstract}
:
The national and international literature and research on SMMEs has been developed very strongly in the last decade. There have been many successful attempts on the part of many researchers and scholars to unpack new and innovative dimensions of SMMEs' operations, behaviour, attitudes, functions and other dynamics that boost, sustain or impede their growth and development. There is, however, a gap in research, regarding a very distinct practice within SMMEs in developing economies, that of bootstrapping. This study, therefore, used a sample chosen on a non-probability basis using convenience sampling of small business owners within the eThekwini Municipality, KwaZulu-Natal, South Africa. 83 participants completed the questionnaire. The study found that the practice of financial bootstrapping was very high amongst the investigated SMMEs. The use of financial bootstrapping within SMMEs is coincidental. The majority of the respondents indicated that they did not undergo any formal training on the use of financial bootstrapping methods.
\end{abstract}

\section{Keywords:}

Developing Economy, Financial Bootstrapping, SMMEs

JEL Classification: L26 


\section{INTRODUCTION}

In recent years, policy makers, commentators and researchers have become more interested in the importance of small businesses. It has been widely recognized that start-ups and more established small businesses play an important role in economic growth and job creation (Kruger, Chantal \& Saunders, 2015; Phillips, Moos, \& Nieman, 2014). In order to improve the economic conditions and poverty issues in developing economies, small businesses can play a vital role because Small, Medium and Micro Enterprises (SMMEs) are generally regarded as the driving force of economic growth and poverty reduction (Okpara, 2011; Amra, Hlatshwayo \& McMillan, 2013; Cant, 2016). SMMEs have been described as the catalyst for economic growth that should be pursued by the South African government to address the scourge of unemployment and low gross domestic product (GDP) growth. While the contributions of small businesses to society development are generally acknowledged, entrepreneurs are faced with many social and economic hurdles that limit their growth and survival (Kruger et al., 2015). In this context the lack of access to capital, resources facing small businesses seems to be an ever-recurring theme (Bruwer \& Van Den Berg, 2017). Given the constraints that small businesses face in acquiring financial capital, there is a need to investigate alternative means of sourcing finance other than the traditional outside funding such as venture and angel capital (Phillips et al., 2014).

\section{PROBLEM STATEMENT}

Despite government's efforts to support and finance SMMEs in developing economies, the failure rate of these businesses is still high (Cant and Wiid, 2013). Within the South African context, SMMEs have ample support from the state through various initiatives, however, up to $75 \%$ of these businesses fail within their three years of operation (Bruwer \& Van Den Berg, 2017). In spite of the arguments made by the aforementioned authors, several studies insist that the major constraint inhibiting SMMEs success is the access to the institutions in the economy that are established to provide funding (Lekhanya, 2015; Kruger et al., 2015; Worku, 2016). Even though it is important to investigate alternative funding mechanisms for SMMEs, of equally importance, is the investigation of their attitudes towards alternative means of sourcing finance other than the traditional funding methods.

\section{AIM AND OBJECTIVES}

\subsection{Aim}

The main aim of this study is to investigate the SMMEs attitudes towards the use of financial bootstrapping as a funding model in the developing economy. 


\subsection{Objectives}

In order to address the aim of this study, the following objectives have been formulated:

> To investigate the awareness and the extent of the use of financial bootstrapping as a means of financing by SMMEs in the developing economy.

$>$ To identify factors that affect the use of financial bootstrapping methods by SMMEs in the developing economy.

\section{LITERATURE REVIEW}

\subsection{Financial bootstrapping defined}

This phenomenon is defined by (Tomory, 2010) as highly creative ways of acquiring the use of resources without borrowing money or raising equity financing from traditional sources. According to Schofield (2015), financial bootstrapping allows small business owners to create new financial resources or stretch existing resources without using debt, a venture capitalist, or other external means to attain required capital. Van Auken and Neeley (2010) further refined the definition of bootstrap financing to include those sources of capital used after exhausting personal savings, but not personal capital or loans from banks. The definition of financial bootstrapping adopted for this study is "the use of highly creative ways for meeting the need for resources without relying on long-term external finance from debt holders and/or new owners" (Vanacker \& Sels, 2009).

\subsection{The use of financial bootstrapping by SMMEs}

Several studies have referred to the financial gap facing small businesses, in terms of problems in attracting long-term finance from market players such as banks, and venture capital companies (Fakoti, 2014; Lekhanya, 2015; Schofield, 2015). The underlying assumption in the research and the public debate is that financial problems generally restrain small businesses' development and growth (Tomory 2010; Amra et al., 2013; Worku, 2016). It is often assumed that small business owners try to raise large sums of money from banks and venture capital companies (Daniel, Di Domenico and Sharma, 2015). It has been stated that much research on small business finance has focused on constraints in the supply of institutional finance, whereas the handling of financial needs at the demand side (i.e. the small business manager's perspective) has been given much less attention (Afolabi, Odebunmi, \& Ayo-Oyebiyi, 2014).

The concept of financial bootstrapping for small businesses originated from Bhide (1992) and it has received increased academic attention, particularly in developed economies (Winborg, 2015). According to Löfqvist (2017), SMMEs engage in bootstrapping approaches to manage scarce resources such as capital and to promote 
product innovation. Löfqvist (2017) adds that resource scarcity in SMMEs hinders these entities from being innovative. Companies without access to formal debt or equity markets can creatively access resources through different means. Innovative financing methods are vital to the survival of new micro enterprises in the retail sector (Fatoki, 2014). According to the resource dependence theory (RDP) by Pfeffer and Salancik (1978) as cited by Drees and Heugens (2013), resources are a cornerstone for an entity's operation and survival. Thus, resources can help a new firm to gain and sustain competitive advantage. Therefore, Entrepreneurs who have trouble in attaining funds or who find external funding undesirable will need to think creatively to meet funding goals (Schofield, 2015).

Problems in securing finance from traditional sources such as angels, venture capitalists and banks for meeting the need for resources may imply that small business owners or managers handle the need for resources using other means. Simply put small business owners and managers must acquire resources without a financial transaction. Outside funders or financiers are generally skeptical of the success potential of small businesses due to information asymmetries, which in turn results in high costs in terms of interest rates, ownership, and control (Winborg, 2015). To manage their capital constraints and to preserve ownership and control of their businesses, small business owners devise methods to acquire essential resources that minimize the amount of outside debt and equity financing needed from banks, angels and venture capitalist (Fatoki, 2014). Afolabi et al. (2014) assert that businesses with higher leverage, lower liquidity, and lower profitability are more likely to bootstrap. However, the general consensus in SMME research, within the developing economy context, is that a very limited number of these organisations use financial bootstrapping (Fatoki, 2014; Afolabi et al., 2014; Schofield, 2015; Zwane \& Nyide, 2016).

\subsection{Factors affecting the use of financial bootstrapping methods by SMMEs}

According to Grichnik, Brinckmann, Singh and Manigart (2013), entrepreneurs with greater levels of human capital in different areas are likely to employ more bootstrapping activities. Entrepreneurs with managerial experience and those who have pursued higher levels of academic education or specific business training engage in bootstrapping to a greater extent (Grichnik et al. 2013). This shows that both specific direct experiences and education can affect bootstrapping. Winborg (2015) contends that the change in SMME life-cycle has a direct impact on the use of financial bootstrapping. The argument is that, at an infant stage, SMMEs struggle to negotiate for external funding. As such, financial bootstrapping becomes an innovative and a low cost approach that these entities can use to establish themselves. Surviving beyond the infancy stage, SMMEs are then able to acquire external funding using the traditional methods (Jonsson \& Lindbergh, 2013; Schofield, 2015). 
Another contributing factor affecting the use of financial bootstrapping is lack of awareness by SMMEs. The majority of small business owners are not aware of financial bootstrapping and its use (Zwane and Nyide, 2016). This argument is in line with Munyanyi (2015) who contends that while awareness of the strategies for financial bootstrapping is evident in literature, more needs to be done. It is, thus, recommended that government ministries, quasi-government institutions aligned to the development of small and medium enterprises and non-governmental organization mandated to rural development intensify the awareness of these and other financial bootstrapping strategies as a way of promoting entrepreneurial activity. Cant, Erdis and Sephapo, 2014) assert that awareness regarding the financial bootstrapping resources available to those who wish to establish their own entities should be increased. Schofield (2015) add that entrepreneurs can begin to mitigate the challenges associated with owning a small business through an increased awareness of alternative financing methods.

\section{RESEARCH METHODOLOGY}

The focus of this research were SMMEs operating within the eThekwini municipality, in KwaZulu-Natal, a province in South Africa. The SMME definition used for the purposes of this this study is "an enterprise which has 50 or fewer employees and/or annual turnover of between R200 000 and R32 million" (Timm, 2011). The target population consisted of all SMMEs registered with the eThekwini Municipality's SMME Database. The sample size of 83 subjects was chosen on non-probability snowball sampling from the population. The study, then employed an electronic questionnaire as a research instrument. Closed - ended questions were developed from literature review as source of information for the questionnaire. The questionnaires were administered on the web through QuestionPro. To ensure reliability, the questionnaire was evaluated based on the Cronbach's Coefficient Alpha as this measure has the most utility for rating scales (Bonett \& Wright, 2015). The Cronbach's Coefficient Alpha for the rating scales used in the questionnaire was 0.791 which is shown in Table 1. A coefficient of 0.791 indicates that internal consistencies of the scale items have been satisfied and that the questionnaire was reliable. The data can therefore be used confidently for further analysis and interpretation.

\section{Table 1. The Cronbach's Coefficient Alpha}

\begin{tabular}{|c|c|c|}
\hline Cronbach's Alpha & $\begin{array}{c}\text { Cronbach's Alpha Based } \\
\text { on Standardized Items }\end{array}$ & Number of Items \\
\hline 0.791 & 0.721 & 8 \\
\hline
\end{tabular}


Table 2. Summary of key questions

\begin{tabular}{|c|c|}
\hline Research objective & Question \\
\hline $\begin{array}{l}\text { To investigate the awareness } \\
\text { and the extent of the use of } \\
\text { financial bootstrapping as a } \\
\text { means of financing by SMMEs } \\
\text { in the developing economy. }\end{array}$ & $\begin{array}{l}\text { 1. Do you know what financial bootstrapping } \\
\text { is? } \\
\text { 2. How long have you been in business? } \\
\text { 3. What is the relationship between the } \\
\text { business's number of years in existence } \\
\text { and the financing method? }\end{array}$ \\
\hline $\begin{array}{l}\text { To identify factors that affect } \\
\text { the use of financial } \\
\text { bootstrapping methods by } \\
\text { SMMEs in the developing } \\
\text { economy. }\end{array}$ & $\begin{array}{l}\text { 4. Which of the bootstrapping methods work } \\
\text { well for your business? } \\
\text { 5. Did you under go any training on how to } \\
\text { use financial bootstrapping methods? }\end{array}$ \\
\hline
\end{tabular}

\section{RESEARCH FINDINGS}

To investigate the respondents' awareness of financial bootstrapping as a means of financing small businesses, respondents were asked if they knew what financial bootstrapping was.

\section{Figure 1. Awareness of financial bootstrapping}

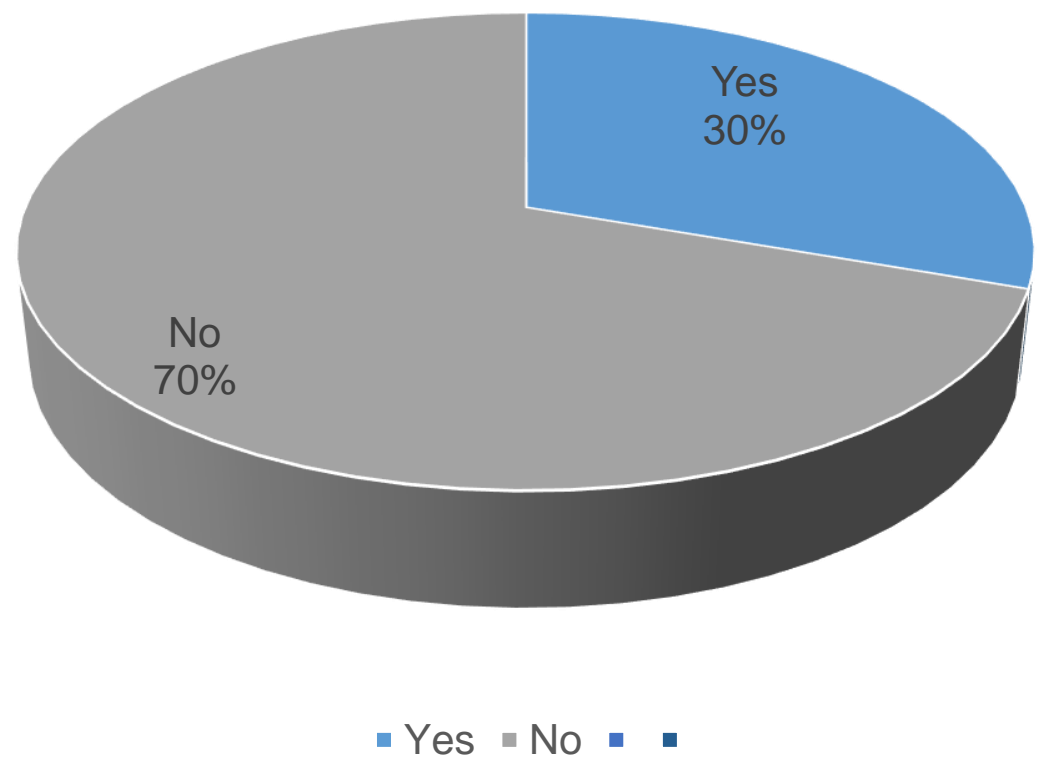


As illustrated in Figure 1, the majority of respondents did not know what financial bootstrapping was (70\%) compared with those who indicated that they knew what it was $(30 \%)$. This finding is supported by other research (Afolabi et al., 2015; Fatoki, 2014). Worku (2016) concurs by adding that one of the key obstacles to the growth and development of SMMEs that are operated in developing economies is the lack of awareness about support programmes such as financial bootstrapping.

Figure 2. Experience in business

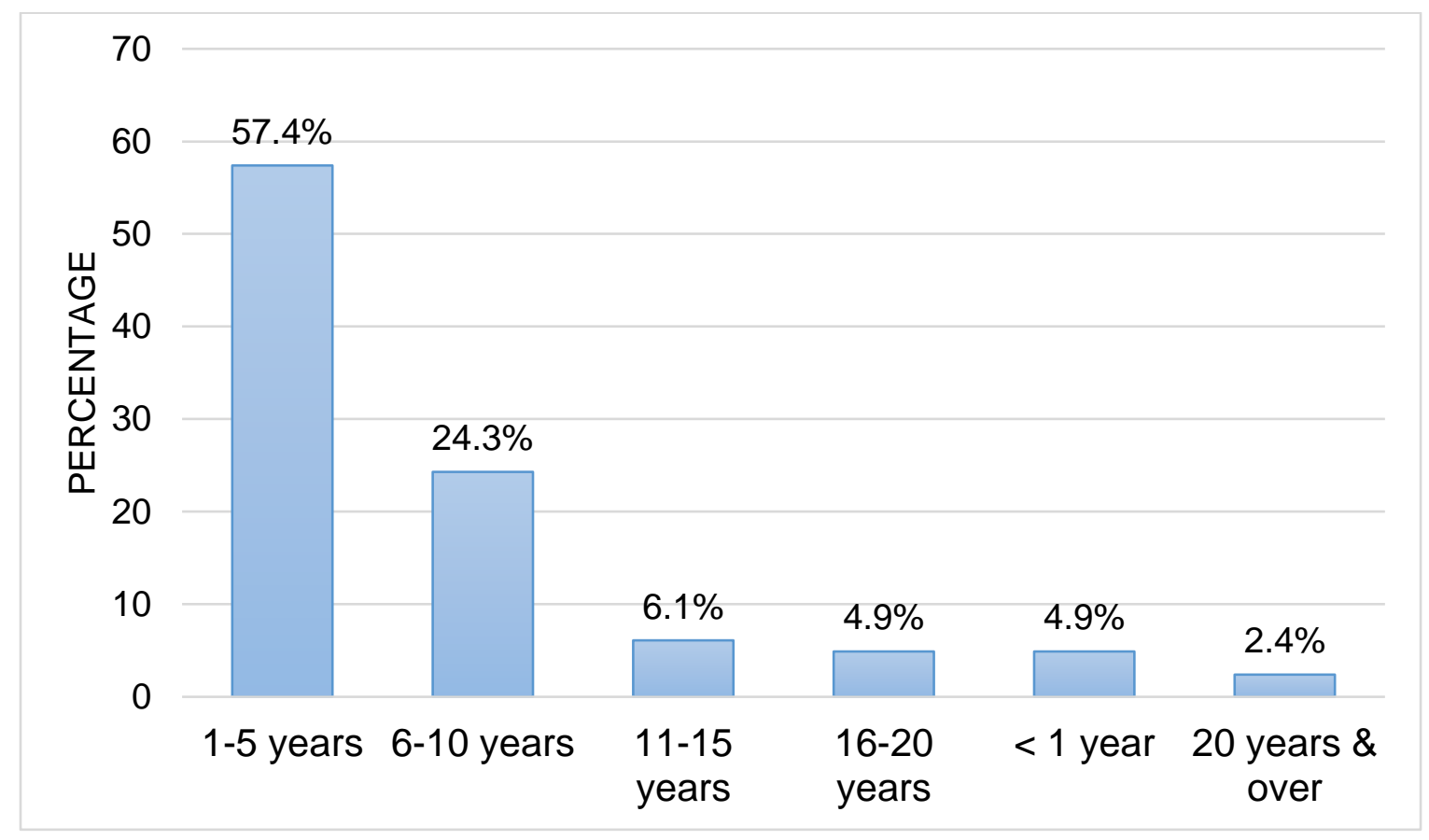

Respondents were asked as to how long they have been in business. As it is illustrated in Figure 2, about $57 \%$ of the respondents indicated that they were in business for a period of between one year to five years. These business are considered to be startup SMMEs and have limited experience (Grichnik et al., 2014). About 5\% of the informants responded that they have been in business for less than one year. The respondents that fall within the experienced cohort that is between 6-10 years amounted to $24 \%, 11-15$ year totalled $6.1 \%, 16-20$ years amounted to just than $5 \%$ and the ones that are 20 years and more in business is only a mere $2.4 \%$. The majority of the studied SMMEs have been in business for less than five years. This implies that even their experience with financial bootstrapping practices is very limited. 
Table 3. Relationship between SMME experience and the funding method

\begin{tabular}{|c|c|c|c|c|c|c|c|}
\hline $\begin{array}{l}\text { Years in } \\
\text { business }\end{array}$ & $\begin{array}{l}\text { Bank } \\
\text { loan }\end{array}$ & $\begin{array}{l}\text { Business } \\
\text { partners }\end{array}$ & $\begin{array}{l}\text { Angel } \\
\text { finance }\end{array}$ & $\begin{array}{l}\text { Venture } \\
\text { capital }\end{array}$ & $\begin{array}{l}\text { Government } \\
\text { funded } \\
\text { business } \\
\text { agencies }\end{array}$ & $\begin{array}{l}\text { Bootstrapping } \\
\operatorname{method}(\mathrm{s})\end{array}$ & Total \\
\hline$<1$ year & $1.1 \%$ & $0 \%$ & $1.1 \%$ & $1.1 \%$ & $0 \%$ & $1.1 \%$ & $4.4 \%$ \\
\hline $\begin{array}{l}1-5 \\
\text { years }\end{array}$ & $7.8 \%$ & $8.9 \%$ & $1.1 \%$ & $1.1 \%$ & $1.1 \%$ & $36.7 \%$ & $56.7 \%$ \\
\hline $\begin{array}{l}6-10 \\
\text { years }\end{array}$ & $6.7 \%$ & $6.7 \%$ & $0 \%$ & $3.3 \%$ & $2.2 \%$ & $8.9 \%$ & $27.8 \%$ \\
\hline $\begin{array}{l}11-15 \\
\text { years }\end{array}$ & $0 \%$ & $1.1 \%$ & $0 \%$ & $0 \%$ & $1.1 \%$ & $3.4 \%$ & $5.6 \%$ \\
\hline $\begin{array}{l}16-20 \\
\text { years }\end{array}$ & $2.2 \%$ & $0 \%$ & $0 \%$ & $0 \%$ & $0 \%$ & $1.1 \%$ & $3.3 \%$ \\
\hline $\begin{array}{l}>\quad 20 \\
\text { years }\end{array}$ & $0 \%$ & $0 \%$ & $0 \%$ & $0 \%$ & $0 \%$ & $2.2 \%$ & $2.2 \%$ \\
\hline Total & $17.8 \%$ & $16.7 \%$ & $2.2 \%$ & $5.5 \%$ & $4.4 \%$ & $53.4 \%$ & $100 \%$ \\
\hline
\end{tabular}

Table 3 depicts the age of the business and the sources of finance used by these businesses. Of all the methods of finance used by these business, $53.4 \%$ is attributed to the financial bootstrapping methods of finance. The balance being linked to the traditional financing methods such as bank loans, business partners, angel financing, venture capital, and government funded business agencies. The vast majority of the business which were in existence for a period that did not exceed 5 years did not receive any support from external financiers to fund their start-ups. Responses indicated that only $1.1 \%$ of businesses that existed for less than a year and $7.8 \%$ of those which existed more than a year but less than 5 years had received a loan from a bank to fund their start-up phase. Of particular interest was the fact that none of the businesses that were in existence for a period of less than a year had received any financial support from government funded supporting agencies and only $1.1 \%$ of respondents in business between 1 year and five years had received financial support from government funded agencies. 
Table 4. The most used financial bootstrapping method

\begin{tabular}{|c|c|c|c|c|c|c|c|}
\hline $\begin{array}{l}\text { Years in } \\
\text { business }\end{array}$ & $\begin{array}{c}\text { Personal } \\
\text { credit } \\
\text { card }\end{array}$ & $\begin{array}{c}\text { Withhold } \\
\text { own } \\
\text { salary }\end{array}$ & $\begin{array}{c}\text { Withhold } \\
\text { profit } \\
\text { earned }\end{array}$ & $\begin{array}{l}\text { Loans } \\
\text { from } \\
\text { friends/ } \\
\text { family } \\
\text { members }\end{array}$ & $\begin{array}{l}\text { Employ } \\
\text { relatives } \\
\text { and } \\
\text { friends at } \\
\text { below- } \\
\text { market } \\
\text { rates }\end{array}$ & $\begin{array}{l}\text { Run } \\
\text { business } \\
\text { completely } \\
\text { from home }\end{array}$ & Total \\
\hline$<1$ year & $1.1 \%$ & $0.5 \%$ & $0 \%$ & $1.6 \%$ & $0 \%$ & $0 \%$ & $3.2 \%$ \\
\hline $\begin{array}{l}1-5 \\
\text { years }\end{array}$ & $5.3 \%$ & $12.8 \%$ & $16.6 \%$ & $6 \%$ & $10.2 \%$ & $15 \%$ & $65.9 \%$ \\
\hline $\begin{array}{l}6-10 \\
\text { years }\end{array}$ & $4.3 \%$ & $6 \%$ & $4 \%$ & $3.2 \%$ & $1.6 \%$ & $0.5 \%$ & $19.6 \%$ \\
\hline $\begin{array}{l}11-15 \\
\text { years }\end{array}$ & $0.5 \%$ & $0.5 \%$ & $1.6 \%$ & $1.1 \%$ & $0.5 \%$ & $0.5 \%$ & $4.7 \%$ \\
\hline $\begin{array}{l}16-20 \\
\text { years }\end{array}$ & $1.6 \%$ & $1.1 \%$ & $1.1 \%$ & $1.1 \%$ & $0 \%$ & $0.6 \%$ & $5.5 \%$ \\
\hline $\begin{array}{l}20 \\
\text { years } \\
\text { and } \\
\text { over }\end{array}$ & $0 \%$ & $0 \%$ & $1.1 \%$ & $0 \%$ & $0 \%$ & $0 \%$ & $1.1 \%$ \\
\hline Total & $12.8 \%$ & $20.9 \%$ & $24.4 \%$ & $13 \%$ & $12.3 \%$ & $16.6 \%$ & $100 \%$ \\
\hline
\end{tabular}

Table 4 shows which of the selected financial bootstrapping methods were used by the respondents according to their years in business. Thus, the table shows that predominantly start-ups are funded by owner related methods compared to outside funding. This finding is congruent with the literature (Jonsson \& Lindbergh, 2013; Grichnik et al., 2014; Munyanyi, 2015). The respondents in the start-up phase indicated that they used personal credit cards $(6.4 \%)$, withhold own salaries $(13.3 \%)$, withhold profits earned from business (16.6\%), loans from friends/family members $(7.6 \%)$, employed relatives and friends at below market rates $(10.2 \%)$ and run businesses completely from their homes (15\%) to finance their businesses. 
Figure 3. Bootstrapping training

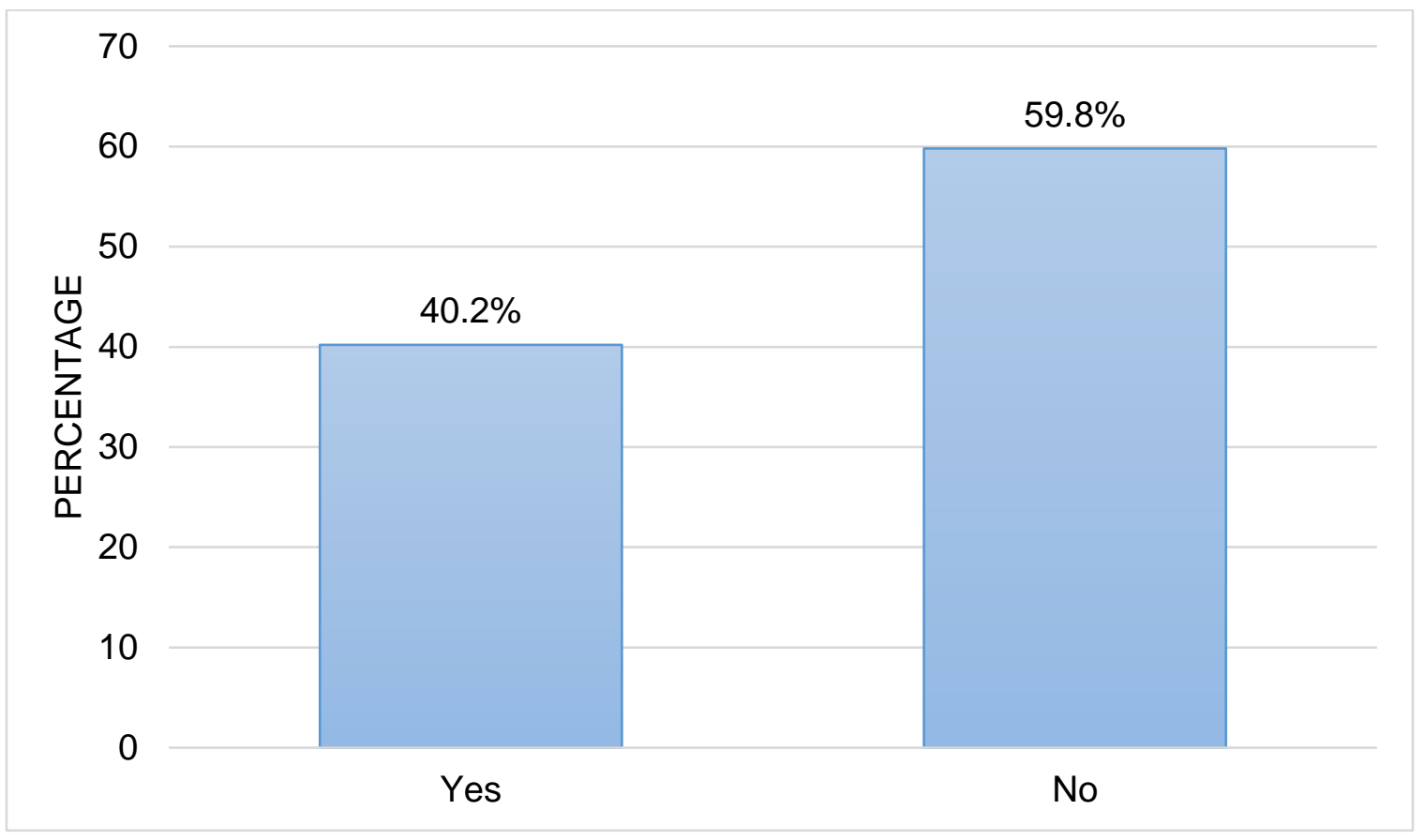

Respondents were asked if there is a formal training they underwent on how to use financial bootstrapping. Figure 4 shows that the majority of respondents $(59.8 \%)$ have not been trained on how to use financial bootstrapping methods. Only $40 \%$ responded that there is some sort of training done on how to use financial bootstrapping methods. (Zwane and Nyide, 2016) argue that most SMMEs use financial bootstrapping unaware. Therefore, even if business owners have no formal training, they inevitable use bootstrapping methods. As it has been indicated in the previous section, accessing external funding is a challenge to SMMEs, hence financial bootstrapping approaches become their only option for survival.

\subsection{Summary of key findings}

The results obtained from the analysis of data have revealed several interesting findings. Some of the most important findings are that the majority of small business owners were not aware of financial bootstrapping and only a few respondents knew what bootstrapping was. However, the study found that most of the respondents were financed by owner-related funds than those small businesses that received any funding from government funded agencies. Whilst many of the respondents did not know what financial bootstrapping was, all respondents were found to be practicing some level of bootstrapping. The use of financial bootstrapping was prevalent amongst SMMEs that are considered to be start-ups. The majority of SMMEs have not done any form of training on how to use financial bootstrapping methods. 


\section{LIMITATIONS}

The following limitations were identified:

- Due to time and funding constraints, the data was collected from a small sample of small businesses within eThekwini Municipality with the hope of generalizing the results to all small businesses in South Africa.

- The findings of the study could not be generalized to all small businesses due to the sampling design and small sample size. Whilst the method of sampling used for this study was appropriate, non-probability purposive sampling is the least reliable in terms of generalization.

- There is limited literature of academic merit relating to financial bootstrapping in South Africa.

\section{IMPLICATIONS}

It can be argued that the practice of financial bootstrapping in the developing economy is still limited. Even though this area of research has received academic interest in international literature, very little is available for academic and business consumption in developing economies. This paper contributes towards the establishment of the awareness of financial bootstrapping approaches by SMMEs in developing economies. Moreover, an attempt was made by this study to ascertain the extent at which financial bootstrapping is used by SMMEs in developing economies.

\section{RECOMMENDATIONS}

> Researchers and entrepreneurship authors should research and write more about alternative business financing sources particularly financial bootstrapping to educate business owners in general and new and/or interested entrepreneurs in particular with regard to these concepts.

> Government funded agencies must have better trained staff members who understand and have knowledge of all funding sources to better service the small business sector and thus encourage applicants to use internal methods for funding as they are both efficient and effective.

$>$ SMMEs need to be educated on the importance of various financial bootstrapping approaches such as sharing resources like premises, machinery and equipment. SMMEs need to be exposed to more financial bootstrapping methods such as employing relatives, friends and students at below market rates and obtain loans from friends and/or relatives in order to save money to be invested in critical areas of the business. 
In this study, the sampling frame used was limited as it basically included Black African respondents. A further study should include a considerable number of all social/racial groups.

Future studies should use probability sampling techniques so that the findings of such studies are more reliable and may be used with greater accuracy in generalising the findings to the entire population of entrepreneurs.

\section{REFERENCES}

Afolabi, Y.A., Odebunmi, A.T., and Ayo-Oyebiyi, J.T. 2014. Bootstrap financing techniques among small enterprises in Osogbo metropolis. Global Business and Economics Research Journal, 3(1): 24 54.

Amra, R., Hlatshwayo, A. and McMillan, L. 2013. SMME Employment in South Africa. In: Biennial conference of Economics Society of South Africa. Bloemfontein, September 25-27, 2013.

Bhide, A (1992). Bootstrap finance: The art of start-ups. Harvard Business Review, 70(6), 109-117.

Bonett, D.G. and Wright, T.A. 2015. Cronbach's alpha reliability: Interval estimation, hypothesis testing, and sample size planning. Journal of Organizational Behavior, 36: 3 - 15.

Bruwer, J.P. and Van Den Berg, A. 2017. The Conduciveness of the South African Economic Environment and Small, Medium and Micro Enterprise Sustainability: A Literature Review. Expert Journal of Business and Management, 5(1), 1 - 12.

Cant, M.C. 2016. The perceived value of advice given to SMMEs at events: catalyst for action or despondency? Problems and Perspectives in Management, 14 (4): 247 - 255.

Cant, M.C., Erdis, C., and Sephapo, C.M. 2014. Business Survival: The Constraints Experienced by South African SMEs in the Financial Sector. International Journal of Academic Research in Business and Social Sciences. 4 (10): 565 - 579.

Cant, M.C. and Wiid, J.A. 2013. Establishing The Challenges Affecting South African SMEs. International Business \& Economics Research Journal. 12 (6): 707 - 716.

Daniel, E. M., Di Domenico, M. L., and Sharma, S. 2015. Effectuation and homebased online business entrepreneurs. International Small Business Journal. 33(8): 799 - 823.

Drees, J.M. and Heugens, P.P.M.A.R. 2013. Synthesizing and Extending Resource Dependence Theory: A Meta-Analysis. Journal of Management, 39(6): 1666 - 1698.

Fatoki, O. 2014. The Financial Bootstrapping Methods Employed by New Micro Enterprises in the Retail Sector in South Africa. Mediterranean Journal of Social Sciences. 5 (3): $72-80$.

Grichnik, D., Brinckmann, J., Singh, L. and Manigart, S. 2013. Beyond environmental scarcity: Human and social capital as driving forces of bootstrapping activities. Journal of Business Venturing, 29: $310-326$. 
Jonsson, S. and Lindbergh, J. 2013. The Development of Social Capital and Financing of Entrepreneurial Firms: From Financial Bootstrapping to Bank Funding. Entrepreneurial Theory and Practice, 37(4): $661-686$.

Kruger, J., Chantal, T. and Saunders, S. 2015. Macro-economic factors influence on South African SMME business performance. In: 19th International Academic Conference, Florence, Italy, September 16, 2015, IISES, $461-481$.

Lekhanya, L.M. 2015. Public outlook on Small and Medium Enterprises as a strategic tool for economic growth and job creation in South Africa. Journal of Governance and Regulation, 4 (4): 412 - 418.

Löfqvist, L. 2017. Product innovation in small companies: Managing resource scarcity through Financial Bootstrapping. International Journal of Innovation Management, 21(2): 1 - 27.

Munyanyi, W. 2015. Winborg and Landstrom's Financial Bootstrapping Strategies and Zimbabwean Rural Entrepreneurs. International Journal of Academic Research in Business and Social Sciences, 5(7): $289-299$.

Okpara, J.O. 2011. Factors constraining the growth and survival of SMEs in Nigeria Implications for poverty alleviation, Management Research Review, 34(2): 156 - 171.

Phillips, M., Moos, M and Nieman, G. 2014. The Impact of Government Support Initiatives on the Growth of Female Businesses in Tshwane South Africa. Mediterranean Journal of Social Sciences, 5(15): $85-92$.

Schofield, R. M. 2015. Relationship Between Bootstrap Financing, Number of Employees, and Small Business Success. DBA. Thesis, Walden University.

Timm, S. 2011. How South Africa can boost support to small businesses - Lessons from Brazil and India. Trade \& Industrial Policy Strategies (TIPS). [online]. Available at: http://www.tips.org.za/files/india brazil 2011 edit s timm.pdf). (Accessed on: 3 June 2016).

Tomory, E.M. 2010. Nurturing innovation through bootstrap financing - An entrepreneurial perspective. [online]. Available at: www.isn.it/bmra/2010/articles. (Accessed on: 1 June 2016)

Van Auken, H. 2004. The Use of Bootstrap Financing Among Small Technology-Based Firms, Journal of Developmental Entrepreneurship, 9(2): 145 - 159.

Vanacker, T. and Sels, L. 2009. Bootstrapping Strategies and Entrepreneurial Growth: a longitudinal study (Summary), Frontiers of Entrepreneurship Research. 29 (1): Article 6.

Winborg, J. 2015. The role of financial bootstrapping in handling the liability of newness in incubator businesses. Entrepreneurship and Innovation, 16 (3): 197 - 206.

Worku, Z. 2016. Barriers to the growth of small, micro and mediumsized business enterprises in the Vaal Triangle region of South Africa. African Journal of Science, Technology, Innovation and Development, 8(2): $134-141$.

Zwane, B.K. and Nyide, C.J. 2016. Financial bootstrapping and the small business sector in a developing economy. Corporate Ownership and Control, 14(1): 433 - 442. 